\title{
Antibacterial Activity of Fractions from Extract Ethanolic of Hylocereus Polyrhizus Peel Against E. Coli and S. aureus
}

Tsania Khusnul Khotimah; Annisa Krisridwany*; Salmah Orbayinah; Sabtanti Harimurti School of Pharmacy, Faculty of Medicine and Health Science, Universitas Muhammadiyah Yogyakarta, Jl Brawijaya, Tamantirto, Kasihan, Bantul, Yogyakarta 55183.

\begin{abstract}
Peel of red dragon fruit (Hylocereus polyrhizus) is one of the plants used as an antibacterial agent as it contains saponin triterpenoid compounds, flavonoid compounds, and alkaloid compounds which can have antibacterial activity. This research aims to determine the antibacterial effect of $n$-hexane, ethyl acetate, and ethanol fraction of red dragon fruit's peel against Escherichia coli and Staphylococcus aureus by the concentration of $10 \mathrm{mg} / \mathrm{ml}$, $20 \mathrm{mg} / \mathrm{ml}, 40 \mathrm{mg} / \mathrm{ml}, 80 \mathrm{mg} / \mathrm{ml}$ dan $160 \mathrm{mg} / \mathrm{ml}$. This research was conducted by using laboratory experiments. The simplicia was macerated with $96 \%$ ethanol and fractionated by $n$-hexane and ethyl acetate. The phytochemical screening of the fraction was $n$ hexane fraction containing saponin and alkaloid, while the ethyl acetate fraction contained saponin and flavonoid. Kanamycin was used as a positive control, while DMSO was used as a negative control. According to this research, the MIC value of ethanol fraction, n-hexane fraction, and ethyl acetate fraction were $80 \mathrm{mg} / \mathrm{ml}, 20 \mathrm{mg} / \mathrm{ml}$, and $80 \mathrm{mg} / \mathrm{ml}$, respectively, for E. coli and all fractions were $10 \mathrm{mg} / \mathrm{ml}$ for $\mathrm{S}$. aureus. Based on the average diameter of the inhibition zone, the largest diameter zone in $\mathrm{E}$. coli was ethyl acetate fraction with $160 \mathrm{mg} / \mathrm{ml}$ concentration that was $10.33 \mathrm{~mm}$. Meanwhile, in $\mathrm{S}$. aureus $\mathrm{n}$-hexane fraction, it was $160 \mathrm{mg} / \mathrm{ml}$, which was $11.20 \mathrm{~mm}$. This result showed that the $\mathrm{n}$ hexane fraction has good gram-positive activity while the ethyl acetate fraction has good activity on gram-negative.
\end{abstract}

Keywords: Anti-bacterial; Escherichia coli; Fraction of Hylocereus polyrhizus; Staphylococcus aureus

\section{Data of article}

Received : 30 Dec 2020

Reviewed : 27 Jan 2021

Accepted : 11 Feb 2021

DOI

10.18196/jfaps.v1i2.11001

Type of article:

Research

\section{INTRODUCTION}

With the development of sciences and diseases, awareness of self-sanitation in Indonesia increases; one of the causes of sanitation-related disease is bacteria. Infection is an emergency problem around the world. The incidence of infection continues to increase from $1 \%$ to $40 \%$ in
Asia ${ }^{1}$. There is currently increasing interest in developing highly effective, not contain toxic agents and natural sources ${ }^{2}$. Natural ingredients as medicine in Indonesia are a part of cultural tradition and have been widely used by the community for centuries. One of the plants used as an antibacterial agent

\footnotetext{
*Corresponding author,e-mail: akrisridwany@umy.ac.id
} 
derived from natural ingredients is Dragon Fruit.

Dragon Fruit is a plant that has an excellent opportunity to be developed in Indonesia. One of the dragon fruit variants is red dragon fruit, which has a delicious taste and many health benefits ${ }^{3}$. Dragon fruit is a rich source of nutrients and minerals, such as vitamin $B_{1}$, vitamin $B_{2}$, vitamin $B_{3}$ and vitamin $C_{1}$, protein, fat, carbohydrates, crude fiber, flavonoid, thiamine, niacin, pyridoxine, cobalamin, glucose, phenolic, betacyanin, polyphenols, carotene, phosphorus, iron, and phytoalbumin 4 . In addition, the red dragon fruit skin is no less beneficial than the fruit flesh. However, the benefits of dragon fruit peel are still not widely known. Thus, currently, the fruit peels are only thrown away without being reprocessed. The previous research found that the peel of red dragon fruit contained flavonoid, alkaloid, terpenoids, thiamin, niacin, pyridoxine, cobalamin, phenolic, polyphenols, carotene, betalain ${ }^{4}$.

Based on the background above, this study aims to determine the antibacterial activity of red dragon fruit's peel (Hylocereus polyrhizus) in various fractions against $E$. coli and $S$. aureus.

\section{METHODS}

This research used an experimental laboratory method with several stages of research: sample preparation, fractionation of ethanolic extract of red dragon peel (Hylocereus polyrhizus), phytochemical screening using thin-layer chromatography, and antibacterial activity test using the disc diffusion method (Kirby-Bauer test). This research was conducted in Pharmaceutical Technology Laboratory and Research
Laboratory in Universitas Muhammadiyah Yogyakarta.

The tools used in this research were Oven (Memmert ${ }^{\circledR}$, Germany), Maceration vessel, Rotary evaporation (Heidolp ${ }^{\circledR}$ ), Waterbath (Memmert ${ }^{\circledR}$ ), TLC Vessel $\left(\right.$ Camag $\left.^{\circledR}\right)$, Silica Gel 6o F254 Plate (Merck $\left.{ }^{\circledR}\right)$, Analytical balance (Ohaus $\left.{ }^{\circledR}\right)$, Separating funnel (Iwaki ${ }^{\circledR}$ ), Measuring cup (Iwaki $\left.{ }^{\circledR}\right)$, Erlenmeyer (Iwaki $\left.{ }^{\circledR}\right)$, Test tube (Iwaki $\left.{ }^{\circledR}\right)$, Test tube rack, Micropipette (Socorex ${ }^{\circledR}$ ), Dropper pipette, Volume pipette (Iwaki $\left.{ }^{\circledR}\right)$, Pipette Measure (Iwaki $\left.{ }^{\circledR}\right)$, Petri dishes (Iwaki $\left.{ }^{\circledR}\right)$, Porcelain dishes (Iwaki ${ }^{\circledR}$ ), Vortex mixer (Gemmy ${ }^{\circledR}$ ) Calipers, Handscoon (Handseol $\left.{ }^{\circledR}\right)$, Masks (Sensi ${ }^{\circledR}$ ). The materials used were red dragon fruit (Hylocereus polyrhizus) obtained from the Kebun Naga Resto Jogja, E. coli colony ATCC 25922 (Yogyakarta Health Laboratory Center), Colony S. aureus ATCC 25923 (Yogyakarta Health Laboratory Center), 96\% Ethanol ( Brataco $\left.{ }^{\circledR}\right), 70 \%$ Ethanol (Brataco $\left.{ }^{\circledR}\right), \mathrm{N}$ hexane $\left(\right.$ Brataco $\left.^{\circledR}\right)$, Ethyl acetate (Brataco $\left.{ }^{\circledR}\right)$, Methanol $\left(\right.$ Brataco $\left.^{\circledR}\right)$, Chlorophome pa (Merck $\left.{ }^{\circledR}\right)$, Aquades (Brataco $\left.{ }^{\circledR}\right)$, Cytoborate reagents, Reagents $\mathrm{NH}_{3}$, Liebermann-Burchard reagent, $1 \% \mathrm{FeCl}_{3}$ reagent, Dragendorff reagent, Nutrient agar (NA) Media (Merck $\left.{ }^{\circledR}\right)$, Nutrient broth (NB) Media, Kanamycin Antibiotic (Meiji $\left.{ }^{\circledR}\right)$, DMSO (Merck $\left.{ }^{\circledR}\right)$.

\section{Procedure}

The red dragon fruit's peel was separated from the flesh, cut into thin pieces, dried under the sun covered in a black cloth, and followed by oven at a temperature of $50^{\circ} \mathrm{C}$ for 7 days or more until dry. After that, it was blended to get dry powder of red dragon fruit's peel.

The dry powder of red dragon fruit's peel was macerated with $96 \%$ ethanol with the 
ingredient ratio: solvent (1:10) for 7 days with a 5 -day maceration and 2 days of remaceration at room temperature and light-tight vessel ${ }^{5}$. The extract solution was filtered and concentrated using rotary evaporation at $50^{\circ} \mathrm{C}$ followed by a water bath at $500 \mathrm{C}-700 \mathrm{C}$ until the ethanolic extract of red dragon fruit's peel was obtained.

The ethanolic extract was later fractionated using the liquid-liquid method with ethanol, ethyl acetate, and nhexane as solvents. First, the ethanolic extract of red dragon fruit's peel was dissolved in a mixture of aqua dest : ethanol (3:7) with the ratio of extract and solution (1:10)w/ $/ \mathrm{v}^{6}$. Furthermore, it was put into a separating funnel and added with $\mathrm{n}$-hexane in a ratio of 1:1; then, it was shaken off and allowed to stand until separated, and the n-hexane fraction was taken. The ethanol extract resulted from the separation with $\mathrm{n}$-hexane was then added ethyl acetate in a ratio of 1:1. It was later shaken off and allowed to stand until separated; thus, the ethyl acetate fraction and ethanol fraction were obtained.

A qualitative analysis test of $n$-hexane fraction, ethyl acetate fraction, and ethanol fraction of red dragon fruit's peel ethanolic extract in this study was carried out on saponins, tannins, flavonoids, and alkaloid compounds using Thin Layer Chromatography (TLC) method and Silica Gel GF254. It was conducted with the mobile phases, namely chloroform: methanol (15:1) for saponin, tannins, and flavonoid, and chloroform: methanol (7:3) for alkaloid 5 . The result was obtained by observing the color of the spots appeared under $254 \mathrm{~nm}$ of ultraviolet light and that the spraying reaction could clarify the spot.

\section{Antibacterial Activity Test}

The antibacterial activity test was carried out using the disc diffusion method. First, the nutrient agar and nutrient broth were prepared, and then the tools and media were sterilized by autoclave at the temperature of $121^{\circ} \mathrm{C}$ for 15 minutes. Media were poured into a petri dish and allowed until it hardened. After that, the bacterial suspension was made on the cold nutrient broth media and incubated at $37^{\circ} \mathrm{C}$ for 24 hours. After that, the bacterial suspension was added with $\mathrm{NaCl}$ 0,9\% until the turbidity level was the same as the McFarland standard no 4 . A series of concentration of each red dragon fruit's peel fraction $(160 \mathrm{mg} / \mathrm{ml}$, $80 \mathrm{mg} / \mathrm{ml}$, $40 \mathrm{mg} / \mathrm{ml}, 20 \mathrm{mg} / \mathrm{ml}, 10 \mathrm{mg} / \mathrm{ml} \mathrm{w} / \mathrm{v}$ ) was made with a dilution system from the main concentration of $160 \mathrm{mg} / \mathrm{ml}$ and obtained from 16omg viscous fraction dissolved in 15\% DMSO. After that, 0,5ml was taken and added $15 \%$ DMSO until $1 \mathrm{ml}$ and homogenized to obtain the concentration of $80 \mathrm{mg} / \mathrm{ml}$ and a concentration of $10 \mathrm{mg} / \mathrm{ml}$.

The antibacterial test used the disc diffusion method by preparing a petri dish containing nutrient agar for $E$. coli and $S$. aureus bacteria. Furthermore, using a sterile swab, each bacteria was spread on the surface of the nutrient medium until the bacteria covered the medium. The paper disc containing the test material was placed on the surface of the media that had been treated with bacteria and incubated for 24 hours at $37^{\circ} \mathrm{C}$. The inhibition zone formed was calculated using a caliper. The test was replicated by 3 times. The minimum inhibitory concentration (MIC) was determined based on the lowest sample concentration that could form an inhibition zone compared to negative controls. 


\section{RESULTS AND DISCUSSION}

\section{Phytochemical screening}

The ethanol fraction, ethyl acetate fraction, and n-hexane fraction of the ethanolic extract of red dragon fruit's peel were tested for phytochemistry using the Thin Layer Chromatography (TLC) method to determine the compounds contained in each fraction with Liebermann-Burchard spots of saponin compounds identification.

The $\mathrm{FeCl}_{3}$ was for tannin compounds, dragendorff reagent for alkaloid compounds, and citroborate and $\mathrm{NH}_{3}$ for flavonoid compounds. Phytochemical screening results are shown in Table 1.
Table 1. Result of Phytochemical Screening

\begin{tabular}{|c|c|c|}
\hline Fraction & $\begin{array}{l}\text { Chemical } \\
\text { Content }\end{array}$ & Explanation \\
\hline \multirow[t]{4}{*}{ n-hexane } & Flavonoid & $(-)$ \\
\hline & Saponin & $(+)$ \\
\hline & Tannin & $(-)$ \\
\hline & Alkaloid & $(+)$ \\
\hline \multirow{4}{*}{$\begin{array}{l}\text { Ethyl } \\
\text { acetate }\end{array}$} & Flavonoid & $(+)$ \\
\hline & Saponin & $(+)$ \\
\hline & Tannin & $(-)$ \\
\hline & Alkaloid & $(-)$ \\
\hline \multirow[t]{4}{*}{ Ethanol } & Flavonoid & $(-)$ \\
\hline & Saponin & $(-)$ \\
\hline & Tannin & $(-)$ \\
\hline & Alkaloid & $(-)$ \\
\hline
\end{tabular}

\section{Antibacterial Activity Test}

A red dragon fruit's peel has antibacterial activity against E.coli and $S$. aureus bacteria. The results of the inhibition zone against E.coli are provided in Table 2, and the inhibition zone against $S$. aureus can be seen in Table 3

Table 2. The measurement result of inhibition zone diameter against $E$. coli bacteria

\begin{tabular}{|c|c|c|c|c|}
\hline \multirow{2}{*}{ Fraction } & \multirow{2}{*}{$\begin{array}{l}\text { Series of } \\
\text { Concentration }(\mathrm{mg} / \mathrm{ml})\end{array}$} & \multicolumn{2}{|c|}{ Replication (mm) } & \multirow{2}{*}{ Average } \\
\hline & & I & II & \\
\hline \multirow[t]{5}{*}{ n-hexane } & 10 & 8.50 & 8.05 & $8.28 \pm 0.32$ \\
\hline & 20 & 11.00 & 8.58 & $9.79 \pm 1.71$ \\
\hline & 40 & 10.50 & $9 \cdot 40$ & $9.95 \pm 0.78$ \\
\hline & 80 & 11.00 & 8.40 & $9.70 \pm 1.84$ \\
\hline & 160 & 7.03 & 7.03 & $7.03 \pm 0.00$ \\
\hline \multirow[t]{5}{*}{ Ethyl acetate } & 10 & 8.70 & 8.53 & $8.61 \pm 0.12$ \\
\hline & 20 & 8.50 & 8.60 & $8.55 \pm 0.07$ \\
\hline & 40 & $9 \cdot 30$ & 9.10 & $9.20 \pm 0.14$ \\
\hline & 80 & 8.70 & 10.15 & $9.43 \pm 1.03$ \\
\hline & 160 & 9.65 & 11.00 & $10.33 \pm 0.95$ \\
\hline \multirow[t]{5}{*}{ Ethanol } & 10 & 8.00 & 8.10 & $8.05 \pm 0.07$ \\
\hline & 20 & $7 \cdot 50$ & 8.83 & $8.16 \pm 0.94$ \\
\hline & 40 & 8.50 & 8.10 & $8.30 \pm 0.28$ \\
\hline & 80 & 9.60 & 10.13 & $9.86 \pm 0.37$ \\
\hline & 160 & 10.20 & 10.33 & $10.26 \pm 0.09$ \\
\hline \multicolumn{2}{|c|}{ Positive control } & 27.70 & 25.70 & $26.70 \pm 1.41$ \\
\hline \multicolumn{2}{|c|}{ Negative control } & 10.30 & 8.20 & $9.25 \pm 1.48$ \\
\hline
\end{tabular}


Table 2. The measurement result of inhibition zone diameter against $S$. aureus bacteria

\begin{tabular}{|c|c|c|c|c|c|}
\hline \multirow[b]{2}{*}{ Fraction } & \multirow{2}{*}{$\begin{array}{l}\text { Series of } \\
\text { Concentration } \\
(\mathrm{mg} / \mathrm{ml})\end{array}$} & \multicolumn{3}{|c|}{ Replication (mm) } & \multirow[b]{2}{*}{ Average } \\
\hline & & I & II & III & \\
\hline \multirow[t]{5}{*}{ n-hexane } & 10 & 9.28 & 10.00 & 10.00 & $9.76 \pm 0.42$ \\
\hline & 20 & 9.20 & 9.15 & 10.95 & $9.77 \pm 1.03$ \\
\hline & 40 & 8.75 & $9 \cdot 58$ & 10.85 & $9.73 \pm 1.06$ \\
\hline & 80 & 11.73 & 10.10 & 10.10 & $10.64 \pm 0.94$ \\
\hline & 160 & 11.00 & 11.00 & 11.60 & $11.20 \pm 0.35$ \\
\hline \multirow[t]{5}{*}{ Ethyl acetate } & 10 & 8.70 & $7 \cdot 55$ & 9.25 & $8.50 \pm 0.87$ \\
\hline & 20 & 6.65 & 8.05 & 8.70 & $7.80 \pm 1.05$ \\
\hline & 40 & 7.20 & 9.40 & 9.40 & $8.67 \pm 1.27$ \\
\hline & 80 & 8.65 & 9.83 & 9.65 & $9.38 \pm 0.63$ \\
\hline & 160 & 6.75 & 10.70 & $9 \cdot 55$ & $9.00 \pm 2.03$ \\
\hline \multirow[t]{5}{*}{ Ethanol } & 10 & 7.50 & 7.10 & 8.50 & $7.70 \pm 0.72$ \\
\hline & 20 & 7.33 & 8.25 & 9.05 & $8.21 \pm 0.86$ \\
\hline & 40 & 8.83 & 9.10 & 8.10 & $8.68 \pm 0.52$ \\
\hline & 80 & 8.15 & 10.35 & 9.95 & $9.48 \pm 1.17$ \\
\hline & 160 & 8.40 & 10.40 & 8.83 & $9.21 \pm 1.05$ \\
\hline \multicolumn{3}{|c|}{ Positive Control } & 39.05 & 33.60 & $39.33 \pm 3.85$ \\
\hline \multicolumn{3}{|c|}{ Negative Control } & 6.25 & 7.00 & $6.62 \pm 0.53$ \\
\hline
\end{tabular}

The test results showed differences in the inhibition zone's diameter produced against $E$. coli bacteria and $S$. aureus bacteria. The difference in the inhibition zone in gram-positive and gram-negative bacteria might be due to differences in the structure of the bacterial walls between gram-positive and gram-negative bacteria, which can affect fraction work because the fraction will affect if it enters the bacterial cell. Gram-negative bacteria have a complex and three-layered cell wall structure; the outer layer is a lipoprotein, the middle layer is liposaccharide which blocks the entry of antibacterial bioactive materials, and the inner layer is peptidoglycan which has a high lipid content7. Meanwhile, gram-positive bacteria have a simpler cell wall structure, which is single-layered with low lipid content, making it easier for bioactive compounds to enter the cell7. The results of phytochemical screening showed that the dragon fruit's peel contained saponin triterpenoids, flavonoids, and alkaloids which could have bacterial activity.

Saponin triterpenoid has a bactericidal effect by causing protein and enzyme leakages in the cell. Saponin can reduce bacterial cell surface tension, thereby increasing permeability and causing leakage in the bacterial cell membrane. Due to the damage to the membrane cell, saponin will diffuse into the cytoplasm and cause the cytoplasm to leak and leave the cell, causing the death of bacteria ${ }^{8}$.

Meanwhile, alkaloids can interfere with the constituent components of peptidoglycan in bacterial cells so that the cell wall is not formed completely, which can lead to bacterial death ${ }^{9}$. In addition, alkaloids are also known as DNA intercalators and can inhibit the bacterial topoisomerase enzyme ${ }^{10}$.

Flavonoid has an antibacterial effect. It forms complex compounds with proteins that damage the membrane and cause cell leakage ${ }^{11}$. Flavonoids also interfere with 
metabolism energy through inhibitory mechanisms of bacterial nucleic acid (DNA and RNA) synthesis and inhibition of cytoplasmic membrane function ${ }^{11}$. This mechanism is the same as the aminoglycoside class of antibiotics, which inhibit protein synthesis and cause damage to the cytoplasmic membrane.

After that, a further test was carried out using Mann-Whitney to determine the difference between the control and test groups on $S$. aureus bacteria. The result was that each test concentration in the nhexane fraction had an inhibitory power against $S$. aureus bacteria. Meanwhile, based on the test results on the ethyl acetate fraction, there was no significant difference between negative control at a concentration of $20 \mathrm{mg} / \mathrm{ml}$. In contrast, there was no significant difference between negative control in the ethanol fraction with a concentration of $20 \mathrm{mg} / \mathrm{ml}$.

\section{Analysis of the Result}

To see whether there was a significant difference between the test groups with the inhibitory power, the test was carried out using the non-parametric Kruskal Wallis test as the result of the data was not normal and homogenous. In terms of the E. coli bacteria, the value of $\mathrm{P}=0.065$ (>0.05) indicated that there was no significant difference between the test group with inhibitory power. In contrast, for $S$. aureus bacteria, the value of $P=$ $0.003(<0.05)$ indicated a significant difference between the test groups with inhibition power. After that, a further test was carried out using Mann-Whitney to determine the difference between the control and test groups on $S$. aureus bacteria.

\section{CONCLUSION}

1. The ethanol fraction, n-hexane fraction, and ethyl acetate fraction of the red dragon fruit's peel ethanolic extract (Hylocereus polyrhizus) had antibacterial activity against $E$. coli and S. aureus bacteria.

2. Ethyl acetate fraction of red dragon fruit's peel contained saponin triterpenoids and flavonoids, while the n-hexane fraction of red dragon fruit's peel contained saponin triterpenoid and alkaloid compounds.

3. The ethanol fraction, n-hexane fraction, and ethyl acetate fraction of the red dragon fruit's peel ethanolic extract showed minimal inhibitory concentration (MIC) at the concentration of $80 \mathrm{mg} / \mathrm{ml}, 20 \mathrm{mg} / \mathrm{ml}$, and $80 \mathrm{mg} / \mathrm{ml}$, respectively, against $E$. coli bacteria. Whereas for $S$. aureus bacteria, each fraction showed MIC at the concentration of $10 \mathrm{mg} / \mathrm{ml}$.

4. The ethanol fraction had the greatest inhibitory power against $E$. coli bacteria at a concentration of $16 \mathrm{omg} / \mathrm{ml}$ and a concentration of $80 \mathrm{mg} / \mathrm{ml}$ against $S$. aureus bacteria. Ethyl acetate fraction had the greatest inhibitory power at a concentration of $160 \mathrm{mg} / \mathrm{ml}$ against $E$. coli and at the concentration of $80 \mathrm{mg} / \mathrm{ml}$ against $S$. aureus bacteria. Furthermore, the n-hexane fraction had the greatest inhibition at a $40 \mathrm{mg} / \mathrm{ml}$ concentration for each bacteria.

\section{ACKNOWLEDGMENT}

We would like to thank the Faculty of Health, Jenderal Achmad Yani University Yogyakarta, for funding this research

\section{REFERENCES}

1. Kemenkes RI. (2011). Riset Kesehatan Dasar; RISKESDAS. Jakarta: Balitbang Kemenkes RI.

2. Shan, B., Cai, Y. Z., Brooks, J. D., \& Corke, H. (2007). The In Vitro 
Antibacterial Activity of Dietary Spice and Medicinal Herb Extracts. International Journal of Food Microbiology, 117(1), pp. 112-119.

3. Zur, N. T., Abbo, S., Bar-Zvi, D., \& Mizrahi, Y. (2004). Genetic Relationships among Hylocereus and Selenicereus Vine Cacti (Cactaceae): Evidence from Hybridization and Cytological Studies. Annals of Botany, 94(4), pp. 527-534.

4. Bellec, F. L., Vaillant, F., \& Imbert, E. (2006), Pitahaya (Hylocereus spp): A new fruit crop, a market with a future, Fruits. The International Journal of Tropical \& Subtropical Horticulture, 61(4), pp. 237-250.

5. Hanani, E., (2015), Analisis Fitokimia. Jakarta: Penerbit Buku Kedokteran EGC.

6. Sari, N. S. (2016). Uji Aktivitas Antioksidan dan Fotoprotektif Fraksi Etilasetat Ekstrak Etanolik Kulit Buah Naga Merah (Hylocereus Polyrhizus) [Skripsi]. Yogyakarta: Universitas Muhammadiyah Yogyakarta.

7. Sani, R. N., Nisa, F. C., Andriani, R. D., \& Maligan, J. M. (2013). Analisis rendmen dan skrining fitokimia ekstrak Etanol Mikroalga Laut Tetraselmis chuii. Jurnal Pangan dan Agroindustri, 2(2), pp. 121-125.

8. Cavalieri, S. J., Rankin, I. D., Harbeck, R. J., Sautter, R. S., McCarter, Y. S., Sharp, S. E., Ortez, J. H., \& Spiegel, C. A. U. (2005). Manual of Antimicrobial Susceptibility Testing. USA: American Society for Microbiology.

9. Darsana, I. G. O., Besung, I. N. K., Mahatmi, H. (2012). Potensi Daun Binahong (Anredera Cordifolia
(Tenore) Steenis) dalam Menghambat Pertumbuhan Bakteri Escherichia coli secara In Vitro Indonesia Medicus Veterinus, 1(3), pp. 337-351.

10. Karou, D., Savadogo, A., Canini, A., Yameogo, S., Montesano, C., Simpore, J., Colizzi, V., \& Traore, A. S. (2005). Antibacterial activity of alkaloids from Sida acuta. African Journal of Biotechnology, 4(12), pp. 1452-1457.

11. Pelczar, M. J., \& Chan, E. C. S. (1988). Dasar-Dasar Mikrobiologi. Jakarta: Universitas Indonesia Press. 